\title{
Subchronic Amitriptyline Influences Open-field Behaviours and Spontaneous Working-memory in Healthy Mice
}

\author{
Onaolapo Adejoke Yetunde ${ }^{1}$, Olabintan Olusegun Oyewole ${ }^{2}$, Onaolapo Olakunle James ${ }^{2, *}$ \\ ${ }^{1}$ Department of Anatomy, Ladoke Akintola University of Technology, Nigeria \\ ${ }^{2}$ Department of Pharmacology, Ladoke Akintola University of Technology, Nigeria
}

Copyright $\bigcirc 2017$ by authors, all rights reserved. Authors agree that this article remains permanently open access under the terms of the Creative Commons Attribution License 4.0 International License

\begin{abstract}
Objective: We assessed the effects of amitriptyline on open-field locomotion, stereotypic behaviours and spatial working-memory in healthy mice. Method: Five groups of mice were administered vehicle (distilled water), scopolamine $(2 \mathrm{mg} / \mathrm{kg})$, or one of three doses of amitriptyline $(5,10$ and $15 \mathrm{mg} / \mathrm{kg})$ for 21 days. Behaviours were assessed after the first and final dose of treatment. Result: Administration of the first dose of amitriptyline was associated with enhanced open-field horizontal locomotion, rearing and grooming; with repeated administration, there was suppression of horizontal locomotion and rearing. A dose-related decrease in Y-maze and radial-arm maze spatial working-memory was also observed after repeated administration. Compared to scopolamine, amitriptyline was associated with a significant reduction in open-field behaviours, but a significantly-higher spatial working-memory score. Conclusion: Repeated administration of amitriptyline in healthy mice was associated with suppression of locomotion and grooming; working-memory deficits were also observed. However, working-memory task performance is significantly better than the scopolamine group.
\end{abstract}

Keywords Amitriptyline, Antidepressant, Amnesia, Novelty-induced Behaviours, Working-memory, Scopolamine

\section{Introduction}

Amitriptyline is primarily used in the treatment of major depression, anxiety, bipolar disorder and attention-deficit hyperactivity disorder [1]. Repurposing has led to its use in the management of migraines, neuropathic pain, fibromyalgia, and as a sleep-aid in insomniacs; meanwhile, research is relentless in defining new roles for old drugs like amitriptyline. Studies have also reported that amitriptyline is a potent activator of microglia and stimulator of 5'-nucleotidase activity [2]; as well as effective in inhibiting tumour necrosis factor and interleukin-b [3]. More recently, researchers like Flament et al [4] reported the efficacy of amitriptyline in the management of eating disorders. Sim et al [5] and Boles et al. [6] also reported clinical evidence of the effectiveness of amitriptyline in the management of cyclic vomiting syndrome. Generally, the discovery of novel therapies for clinical conditions is a desirable end-point for a number of academic or scientific objectives.

Amitriptyline is a mixed serotoninergic and noradrenergic uptake inhibitor with strong anticholinergic and antihistaminergic effects. Amitriptyline prevents the uptake of norepinephrine and serotonin in adrenergic and serotonergic neuron by inhibiting the membrane pump mechanism responsible for amine uptake. This may result in the potentiation of neuronal response; largely because reuptake of these biogenic amines is crucial in the termination of neuronal impulses [7] Amitriptyline has also been reported to potentiate dopamine-induced hyperlocomotion [8], via its effects on dopamine receptors $\left(D_{2} / D_{3}\right)$ [8, 9]. The interference with the reuptake of norepinephrine and/or serotonin is believed to underlie the antidepressant activity of amitriptyline. However, common adverse-effects (such as blurring of vision, dry mouth, and constipation) which may limit amitriptyline use have been attributed to its anticholinergic effects; while sedation is thought to be a result its histamine receptor blockade activity. For any drug, adverse-effects presenting with behavioural symptoms (sometimes referred to as behavioural-toxicity) has been suggested as an aspect of drug-tolerability which is often overlooked. It has been defined as the extent to which a drug can disrupt abilities crucial to the safe performance of the cognitive and psychomotor tasks of everyday life [10]. An uncontrolled level of behavioural toxicity can be counter-therapeutic in the use of drugs like amitriptyline, 
since it may exacerbate cognitive dysfunction associated with depression; thereby reducing compliance.

Amitriptyline's effects on brain neurotransmitters, receptors and biogenic amines $[8,9,11]$ have been studied extensively; but usually within the context of its antidepressant or analgesic properties. Drugs with anticholinergic effects e.g. milnacipran and scopolamine are known to impair memory $[11,12]$; also, a few studies have reported evidence of memory-impairment $[13,14]$ following amitriptyline administration. Parra et al [15] reported retrograde amnesia in the passive avoidance task, which was unrelated to anxiety response. However, there is a dearth of information on the general behavioural response to amitriptyline administration (especially in health), using validated animal models like the open-field, Y-maze and/or radial-arm maze.

The objectives of this study were to assess the effects of amitriptyline, at doses in mice that translate to a human equivalent dose of between $0.41-1.22 \mathrm{mg} / \mathrm{kg} /$ day (which falls within the therapeutic dose range in humans, irrespective of gender), on open-field novelty-induced behaviours and spatial working-memory in healthy mice. We also compared the effects of amitriptyline at these doses to those observed with a non-selective anticholinergic and standard amnesic agent (scopolamine) [16]. This was with the view of ascertaining if repeated administration of increasing doses of amitriptyline is associated with significant changes in open-field novelty-induced behaviours and deterioration of working-memory; and how the degree of these changes (if present), is comparable to that of scopolamine. Scopolamine is an atropine alkaloid, and a competitive muscarinic cholinergic receptor antagonist, which induces cognitive deficits [17], and alteration in locomotor activity [18-20] and sleep stages [21]. It is a very potent psychoactive drug validated for its use as a standard/reference drug for inducing amnesia in mammals. The choice of scopolamine as a reference drug is premised on its possession of both cognitive (amnesia) and non-cognitive effects, (locomotor hyperactivity) in rodents $[19,20]$; hence, it is suitable as reference in assessing the extent of the anticholinergic effect of amitriptyline. The rationale for the study was to ascertain the neurobehavioural response to amitriptyline, in health. We tested the hypothesis that, repeated oral administration of amitriptyline could significantly influence open field novelty-induced behaviours, Y-maze and radial-arm spatial working-memory in healthy mice.

\section{Materials and Methods.}

\subsection{Drugs}

Amitriptyline hydrochloride (Amitriptyline $\mathrm{Hcl} 25 \mathrm{mg}$ tablet, Densa Pharmaceutical Ltd. Mumbai, India), Scopolamine (Locin ${ }^{\circledR}$ as Hyoscine N-butylbromide, 10
mg/mL, Greenfield Pharmaceuticals Ltd. Jiang Su, China).

\subsection{Animal Care}

Male, Swiss mice (Empire Breeders, Osogbo, Osun State, Nigeria) weighing $18-20 \mathrm{~g}$ each were used for this study. Mice were housed in groups of five, in enriched (transparent plastic cages with exercise ladders, shredded-paper beddings, artificial burrows made of plastic tubes and platforms) cages, located in a temperature-controlled quarters (22-25 degree Celsius) with 12 hours of light daily (lights on at 7.00 a.m.). All animals were fed commercial standard chow (Calories: $29 \%$ protein, $13 \%$ fat, $58 \%$ carbohydrate) from weaning. Animals had access to food and water ad-libitum, except during the behavioural tests. All procedures were conducted in accordance with the approved institutional protocols and within the provisions for animal care and use prescribed in the scientific procedures on living animals, European Council Directive (EU2010/63).

\subsection{Experimental Method}

Fifty mice were randomly assigned into five groups of ten $(\mathrm{n}=10)$ mice each. Animals received vehicle (oral distilled water at $10 \mathrm{ml} / \mathrm{kg}$, and an intraperitoneal (i.p) injection at 2 $\mathrm{ml} / \mathrm{kg})$ or one of three oral doses of amitriptyline $(5,10$ and $15 \mathrm{mg} / \mathrm{kg}$ ), plus i.p injection of distilled water. A fifth group of animals received i.p. injection of a standard amnesic (scopolamine at $2 \mathrm{mg} / \mathrm{kg}$ ), plus oral distilled water at 10 $\mathrm{ml} / \mathrm{kg}$. Treatments were given daily for 21 days. Doses of amitriptyline were calculated by dissolving weighed quantities in distilled water; and given at a volume of 10 $\mathrm{ml} / \mathrm{kg}$. Behavioural tests were conducted after first and last dose of the vehicle, scopolamine or amitriptyline.

\subsubsection{Behavioural Testing}

Open field novelty-induced behaviours such as locomotion, rearing and grooming were assessed after the initial and final dose of the vehicle, scopolamine and amitriptyline. Behavioural tests were conducted in a quiet room between 10 a.m. and 3 p.m. On each of the test days, mice were transported in their home-cages to the behavioural testing laboratory, and allowed to acclimatise for 30 minutes before administration of treatments. Behavioural tests were conducted in a room lit by white fluorescent light; delivering about 130 Lux at the centre of the arena. Thirty minutes after administration of drug or vehicle, behavioural tests were conducted. Animals were allowed to explore the open-field (for 20 minutes first) and then the Y-maze (5 minutes), after which they were immediately placed in the radial-arm maze (for another 5 minutes). At the beginning of the behavioural tests, each animal was placed in the apparatus and its behaviour videotaped by a ceiling-mounted digital video camera (SMX-F543B), placed 1.5 metres above the arena for subsequent analysis. After testing, each mouse was removed from the maze and returned to its home cage, and 
all interior surfaces cleaned thoroughly with $70 \%$ ethanol, and then wiped dry. At least, 5 minutes was allowed between the testing of individual animals to ensure that the maze was completely dry, and that dispersal of the residual odour of alcohol had occurred. The behavioural parameters were later scored by two independent observers who were blind to the groupings.

\subsubsection{Open Field Novelty-Induced Behaviours}

A twenty minute-period of the following behavioural states: locomotion, rearing and grooming were observed in the open-field, and scored. The open field apparatus is a rectangular arena made of white-painted wood, measuring 36 x 36x $26 \mathrm{~cm}$. The floor is made of hard wood and divided by permanent red markings into 16 equal-sized squares. The mice were placed in the centre of the field and covered by a small dome for (5 seconds), which was removed at the beginning of the 20 minutes countdown. Generally, spontaneous motor activity was monitored in the open-field as previously described [22, 23]. Thirty minutes after administration of the vehicle, scopolamine or amitriptyline, each mouse was introduced into the field and the total horizontal locomotion (number of floor units entered with all paws), rearing frequency (number of times the animal stood on its hind legs either with its fore-arms against the walls of the observation cage or free in the air) and frequency of grooming (number of body cleaning with paws, picking of the body and pubis with the mouth, and face- washing actions, indicative of a stereotypic behaviour) within the 20 minute period was recorded.

\subsubsection{Memory ( $\mathrm{Y}$ and Radial-Maze)}

Y-maze and the radial-arm maze were used to measure general activity and spatial working-memory. Spontaneous alternation behaviour ( $\mathrm{SAB}$ ) was used to measure spatial working-memory. SAB comprises the tendency for rodents to alternate their (conventionally) non-reinforced choices of Y-maze or radial maze arms on successive opportunities. The Y-maze spontaneous alternation has been validated in rodents as a measure of working-memory, general locomotor activity and stereotypic behaviour. Spontaneous alternation was assessed using a Y-maze made of white painted wood with three equally-spaced arms $\left(120^{\circ}, 41 \mathrm{~cm}\right.$ long, $15 \mathrm{~cm}$ high and $5 \mathrm{~cm}$ wide). The floor was also made of hard wood and painted white. Each mouse was placed in one of the arm compartments and allowed to move freely until its tail completely entered another arm. The sequence of arm entries was recorded. An alternation was defined as entry into all three arms consecutively. The number of actual alternations is number of sequential arm entries into the three arms, designated $\mathrm{A}, \mathrm{B}$ and $\mathrm{C}$. The percentage alternation is calculated as $\{$ (Actual alternations/Total arm entry minus two) $\mathrm{x} 100\}$ within a 5 minute period $[24,25]$.

Spatial working-memory in the radial-arm maze was measured as sequential arm entries before making an error.
The apparatus is made of white painted wood with eight equidistantly spaced arms, each about $33 \mathrm{~cm}$ long, $15 \mathrm{~cm}$ high and $5 \mathrm{~cm}$ wide, all radiating from a small central circular platform. Working-memory was assessed when the rat enters each arm a single time. Re-entry into the arms would result in a working-memory error [25].

\subsection{Statistical Analysis}

Data was analysed using Chris Rorden's ezANOVA for windows, version 0.98 . Hypothesis testing was performed using analysis of variance (ANOVA). We tested the hypothesis that a single or repeated oral administration of amitriptyline could significantly alter open-field novelty-induced behaviours and spatial working-memory in healthy mice. Two-factor ANOVA (one between subject, one within subject) was used to test effects of 2 main factors: treatment (five levels: vehicle, scopolamine, and amitriptyline at 5,10 and $15 \mathrm{mg} / \mathrm{kg}$ ) and repeated administration (2 levels: initial and final administration) on behaviours in the open-field, Y-maze and radial-arm maze. Tukey's honest significant difference (HSD) test was used for within and between group comparisons. Results were expressed as mean \pm S.E.M and $p$ values less than 0.05 were considered statistically significant.

\section{Results}

\subsection{Effects of Amitriptyline on Horizontal Locomotion}

Figure 1 (upper panel) shows the effect of vehicle (VEH), scopolamine (SCOP) and amitriptyline on horizontal locomotion; measured as the number of lines crossed within a 20 minute period. A two-factor ANOVA assessing the main effect of treatment and/or repeated administration, revealed a significant effect of treatment $\left(\mathrm{F}_{(4,50)}=33.06\right.$, $\mathrm{p}<0.001)$ and a significant effect of repeated administration $\left(F_{(1,50)}=65.4, p<0.001\right)$, with significant interactions between treatment $x$ repeated administration $\left(\mathrm{F}_{(4,50)}=20.1\right.$, $\mathrm{p}<0.001)$. Tukey HSD analysis revealed a significant increase in horizontal locomotion with SCOP $(p<0.001)$, and amitriptyline at $5(\mathrm{p}<0.001) 10(\mathrm{p}<0.001)$ and $15 \mathrm{mg} / \mathrm{kg}$ $(p<0.001)$ compared to vehicle, following initial administration. With repeated administration, horizontal locomotion increased significantly with SCOP $(p<0.001)$ and decreased with amitriptyline at $5(\mathrm{p}<0.001)$, and 10 $\mathrm{mg} / \mathrm{kg}(\mathrm{p}<0.001)$. Compared to SCOP control, horizontal locomotion was significantly higher with amitriptyline at 10 $\mathrm{mg} / \mathrm{kg}(\mathrm{p}<0.002)$ and significantly less with amitriptyline at $15 \mathrm{mg} / \mathrm{kg}(\mathrm{p}<0.012)$ following initial administration; with repeated administration locomotor activity was significantly less with amitriptyline at $5(\mathrm{p}<0.002), 10(\mathrm{p}<0.040)$ and 15 $\mathrm{mg} / \mathrm{kg}(\mathrm{p}<0.020)$. Pairwise comparisons of the effect of repeated administration revealed horizontal locomotion 
which was significantly less with repeated administration of amitriptyline at $5(\mathrm{p}<0.001)$ and $10 \mathrm{mg} / \mathrm{kg} \quad(\mathrm{p}<0.001)$ compared to initial administration.

\subsection{Effects of Amitriptyline on Rearing}

Figure 1 (lower panel) shows the effect of treatment on rearing, measured as the number of times the animal stood on its hind legs either with its fore-arms against the walls of the observation cage or free in the air, within a 20 minute period. A two-factor ANOVA, assessing the main effect of treatment and/or repeated administration, revealed a significant effect of treatment $\left(\mathrm{F}_{(4,50)}=18.10, \mathrm{p}<0.001\right)$ and a significant effect of repeated administration $\left(\mathrm{F}_{(1,50)}=29.2, \mathrm{p}<0.001\right)$, with significant interactions between treatment $\mathrm{x}$ repeated administration $\left(\mathrm{F}_{(5,50)}=10.12, \mathrm{p}<0.001\right)$. Tukey HSD analysis revealed a significant increase in rearing with SCOP $(p<0.001)$ and amitriptyline at $5(p<0.001), 10(p<0.001)$ and $15 \mathrm{mg} / \mathrm{kg}(\mathrm{p}<0.001)$ compared to vehicle, following initial administration; while with repeated administration, there was a significant increase in rearing with SCOP $(p<0.001)$ and a significant decrease with amitriptyline at $5(\mathrm{p}<0.001)$, $10(p<0.002)$ and $15 \mathrm{mg} / \mathrm{kg}(\mathrm{p}<0.010)$. Compared to SCOP control, rearing activity was significantly less with amitriptyline at $5(\mathrm{p}<0.001), 10(\mathrm{p}<0.001)$ and $15 \mathrm{mg} / \mathrm{kg}$ $(p<0.001)$ with repeated administration and showed no significant difference with initial administration. Pairwise comparisons of the effect of repeated administration and initial administration revealed a significantly less rearing activity with repeated administration of amitriptyline at 5 $(p<0.001)$ and $10 \mathrm{mg} / \mathrm{kg} \quad(\mathrm{p}<0.001)$ compared to initial administration.

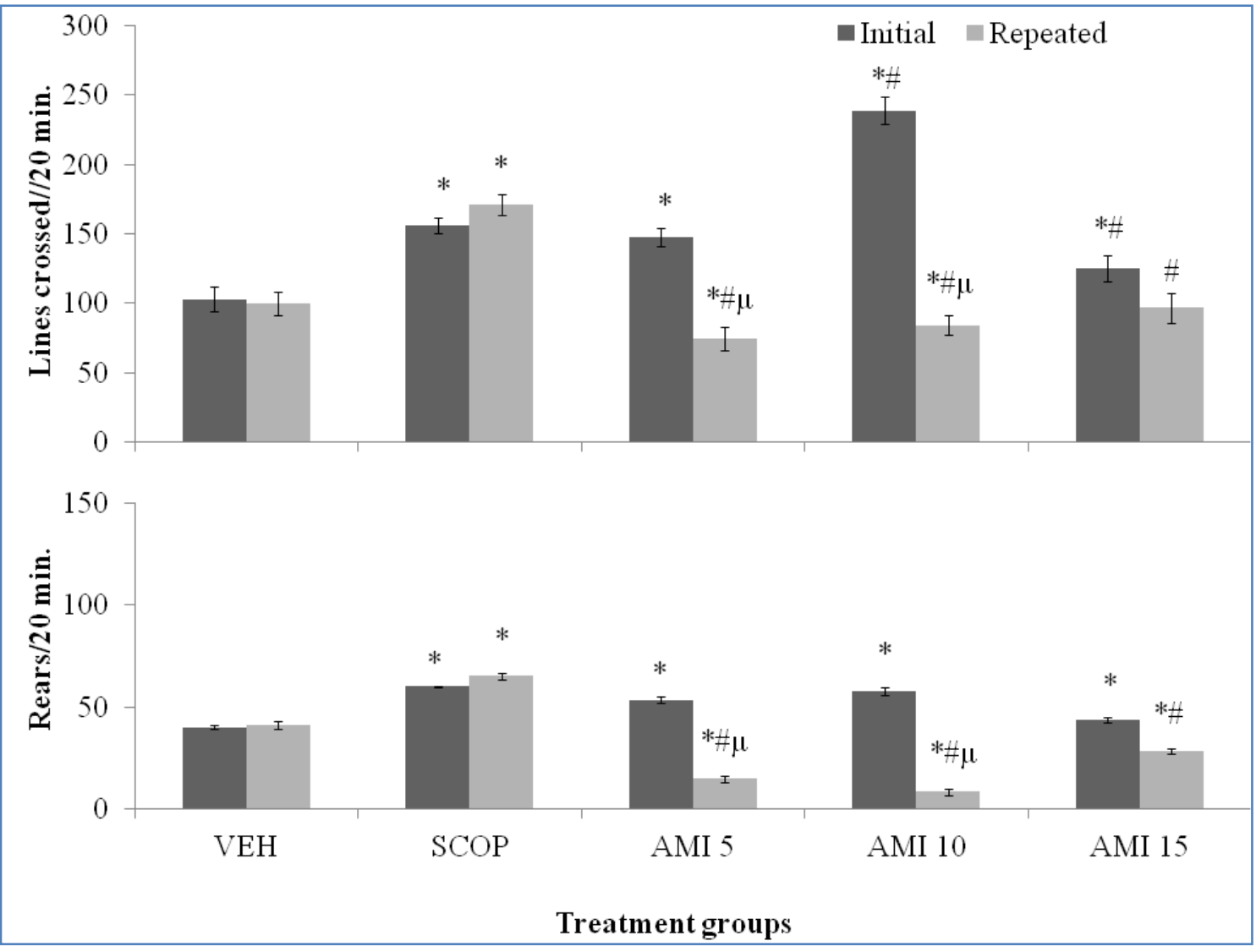

Figure 1. Effect of amitriptyline on horizontal locomotion (upper panel) and rearing activity (lower panel). Values are means \pm S.E.M. ( ${ }^{*}$ p $<0.05$ significantly different from VEH, ${ }^{p}<0.05$ significantly different from SCOP, ${ }^{\mu} \mathrm{p}<0.05$ repeated administration significantly different from initial administration). VEH: Vehicle, SCOP: Scopolamine, AMI: Amitriptyline, number of animals per group-10. 


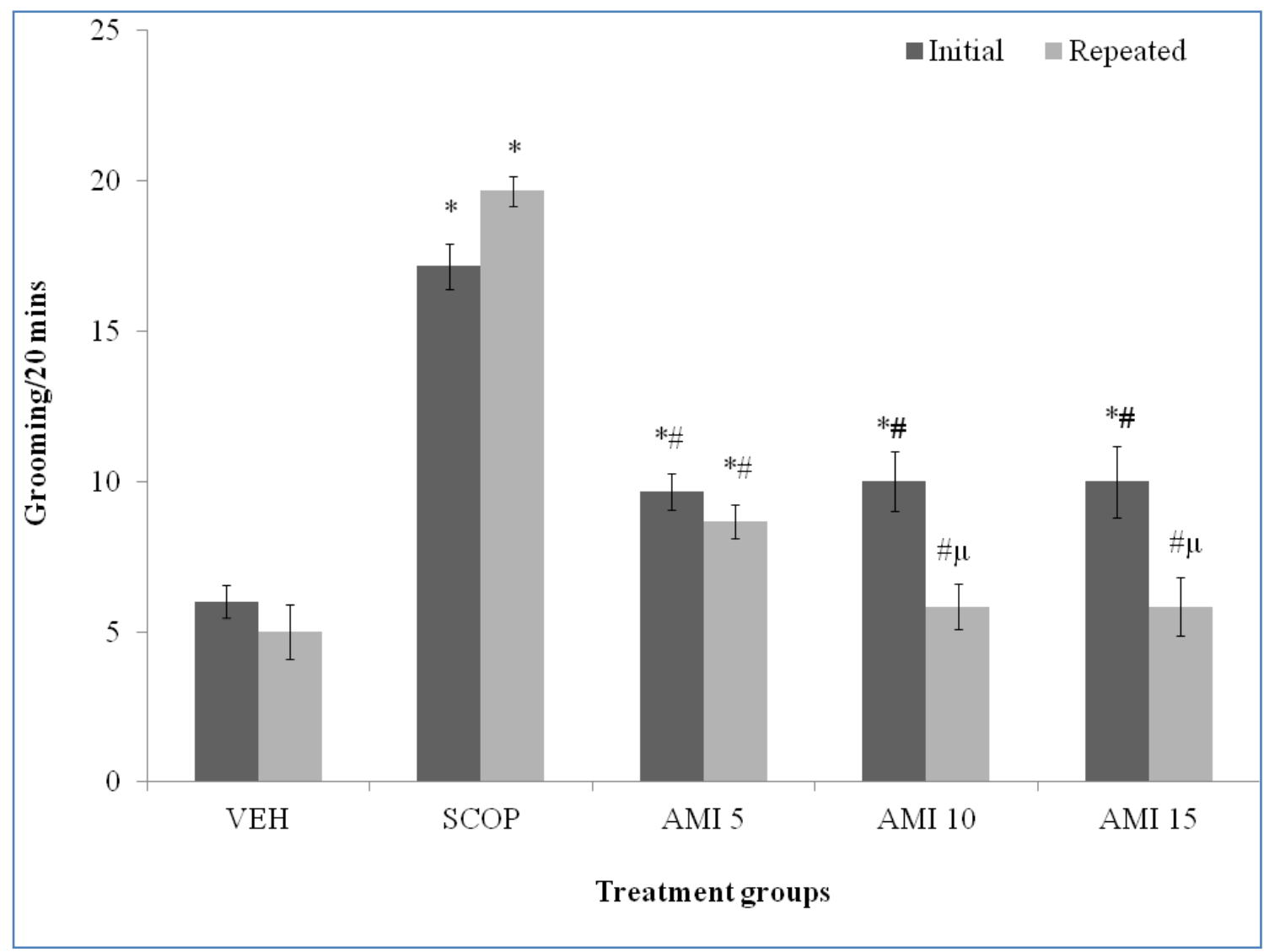

Figure 2. Effect of amitriptyline on grooming behaviour. Values are means \pm S.E.M. ( ${ }^{*} \mathrm{p}<0.05$ significantly different from VEH, ${ }^{\#} \mathrm{p}<0.05$ significantly different from SCOP, ${ }^{\mu} \mathrm{p}<0.05$ repeated administration significantly different from initial administration). VEH: Vehicle, SCOP: Scopolamine, AMI: Amitriptyline, number of animals per group-10.

\subsection{Effects of Amitriptyline on Grooming}

Figure 2 shows the effect of vehicle (VEH), scopolamine (SCOP) and amitriptyline on grooming behaviour, measured as the number of body-cleaning episodes with paws, picking of the body and pubis with mouth and/or face washing actions within a 20 minute period. A two-factor ANOVA assessing the main effect of treatment and/or repeated administration, revealed a significant effect of treatment $\left(\mathrm{F}_{(4,}\right.$ $\left.{ }_{50)}=34.2, \mathrm{p}<0.001\right)$ and a significant effect of repeated administration $\left(\mathrm{F}_{(1,50)}=9.56, \mathrm{p}<0.010\right)$, with no significant interactions between treatment $x$ repeated administration $\left(\mathrm{F}_{44}\right.$, $\left.{ }_{50)}=0.98, \mathrm{p}<0.496\right)$. Tukey HSD analysis revealed a significant increase in grooming with SCOP $(\mathrm{p}<0.001)$, amitriptyline at $5(\mathrm{p}<0.001), 10(\mathrm{p}<0.001)$ and $15 \mathrm{mg} / \mathrm{kg}$ $(p<0.001)$ compared to vehicle following initial administration; and a significant increase with SCOP $(p<0.001)$ and amitriptyline at $5(p<0.001)$ with repeated administration. Compared to SCOP control grooming was significantly lesser with amitriptyline at $5 \mathrm{mg} / \mathrm{kg}(\mathrm{p}<0.001$, $10(\mathrm{p}<0.001)$ and $15 \mathrm{mg} / \mathrm{kg}(\mathrm{p}<0.001)$ following initial and repeated administration, Pairwise comparisons of the effect of repeated administration revealed significantly less grooming with repeated administration of amitriptyline at 10 $(\mathrm{p}<0.010)$ and $15 \mathrm{mg} / \mathrm{kg}(\mathrm{p}<0.011)$ compared to initial administration.

\subsection{Effects of Amitriptyline on Y-Maze Spatial Working-Memory}

Figure 3 (upper panel) shows the effects of vehicle (VEH), scopolamine (SCOP) and amitriptyline on spatial working-memory in the $\mathrm{Y}$-maze, measured as the percentage alternation within a 5 minute period. A two-factor ANOVA assessing the main effect of treatment and/or repeated administration, revealed a significant effect of treatment $\left(\mathrm{F}_{(4,}\right.$ $\left.{ }_{50)}=18.9, p<0.001\right)$, and no significant effect of repeated administration $\left(\mathrm{F}_{1,50)}=0.341, \mathrm{p}<0.561\right)$. However, there were significant interactions between treatment $\mathrm{x}$ repeated administration $\left(\mathrm{F}_{(4,50)}=4.42, \mathrm{p}<0.011\right)$. Tukey HSD analysis revealed a significant decrease in spatial memory with SCOP $(\mathrm{p}<0.001)$ and amitriptyline at $5 \mathrm{mg} / \mathrm{kg}(\mathrm{p}<0.020)$ compared to vehicle, following initial administration; while with repeated administration, spatial memory decreased with SCOP $(p<0.001)$, and amitriptyline at $10(p<0.027)$ and 15 $\mathrm{mg} / \mathrm{kg} \quad(\mathrm{p}<0.022)$. Compared to SCOP control, spatial memory was significantly higher with amitriptyline at 5 $(\mathrm{p}<0.001), 10(\mathrm{p}<0.001)$ and $15 \mathrm{mg} / \mathrm{kg}(\mathrm{p}<0.001)$ following initial and repeated administration. Pairwise comparisons of the effect of repeated administration revealed no significant difference in spatial working-memory with repeated administration of amitriptyline compared to initial administration. 


\subsection{Effects of Amitriptyline on Y-Maze Locomotor Activity}

Figure 3 (lower panel) shows the effect of vehicle, scopolamine or amitriptyline on locomotor activity in the Y-maze, measured as total arm entry within a 5 minute interval. A two-factor ANOVA assessing the main effect of treatment and/or repeated administration, revealed a significant effect of treatment $\left(\mathrm{F}_{(4,50)}=27.3, \mathrm{p}<0.001\right)$ and repeated administration $\left(\mathrm{F}_{(1,50)}=12.80, \mathrm{p}<0.001\right)$, with significant interactions between treatment $\mathrm{x}$ repeated administration $\left(\mathrm{F}_{(4,50)}=13.30, \mathrm{p}<0.001\right)$. Tukey HSD revealed a significant increase in total arm entry with SCOP $(\mathrm{p}<0.001)$, amitriptyline at $5(\mathrm{p}<0001), 10(\mathrm{p}<0.001)$ and 15 $\mathrm{mg} / \mathrm{kg} \quad(\mathrm{p}<0.001)$ compared to vehicle following initial administration; while with repeated administration there was a significant increase in arm entry with SCOP $(p<0.001)$, and a significant decrease in arm entry with amitriptyline at 5 $(\mathrm{p}<0.001)$ and $10 \mathrm{mg} / \mathrm{kg}(\mathrm{p}<0.001)$. Compared to SCOP control, arm entry was significantly less with amitriptyline at $5 \quad(p<0.001)$ following initial administration, and significantly less with amitriptyline at $5(\mathrm{p}<0.001), 10$ $(\mathrm{p}<0.001)$ and $15 \mathrm{mg} / \mathrm{kg} \quad(\mathrm{p}<0.001)$ with repeated administration. Pairwise comparisons of the effect of repeated administration revealed significantly less arm entry with repeated administration of amitriptyline at $10(\mathrm{p}<0.002)$ and $15 \mathrm{mg} / \mathrm{kg}(\mathrm{p}<0.012)$ compared to initial administration.

\subsection{Effects of Amitriptyline on Spatial Working Memory (Radial-Arm Maze)}

Figure 4 (upper panel) shows the effect of vehicle, scopolamine and amitriptyline on spatial working-memory in the radial-arm maze, measured as arm entry before first error within a 5 minute period. A two-factor ANOVA assessing the main effect of treatment and/or repeated administration, revealed a significant effect of amitriptyline dose $\left(\mathrm{F}_{(4,50)}=8.70, \mathrm{p}<0.001\right)$, a significant effect of repeated administration $\left(\mathrm{F}_{(1,50)}=8.20, \mathrm{p}<0.001\right)$, and significant interactions between treatment $x$ repeated administration $\left(\mathrm{F}_{(4}\right.$, $\left.{ }_{50)}=4.80, \mathrm{p}<0.010\right)$. Tukey HSD analysis revealed a significant decrease in spatial memory with SCOP $(p<0.010)$ compared to vehicle following initial and repeated administration; and a significant decrease with amitriptyline at $10(\mathrm{p}<0.032)$ and $15 \mathrm{mg} / \mathrm{kg}(\mathrm{p}<0.023)$ following repeated administration. Compared to SCOP control, spatial memory was significantly higher with amitriptyline at $5(\mathrm{p}<0.001), 10$ $(p<0.011)$ and $15 \mathrm{mg} / \mathrm{kg}(\mathrm{p}<0.001)$ following initial and repeated administration. Pairwise comparisons of the effect of repeated administration revealed no significant difference in spatial working memory with repeated administration of amitriptyline compared to initial administration.

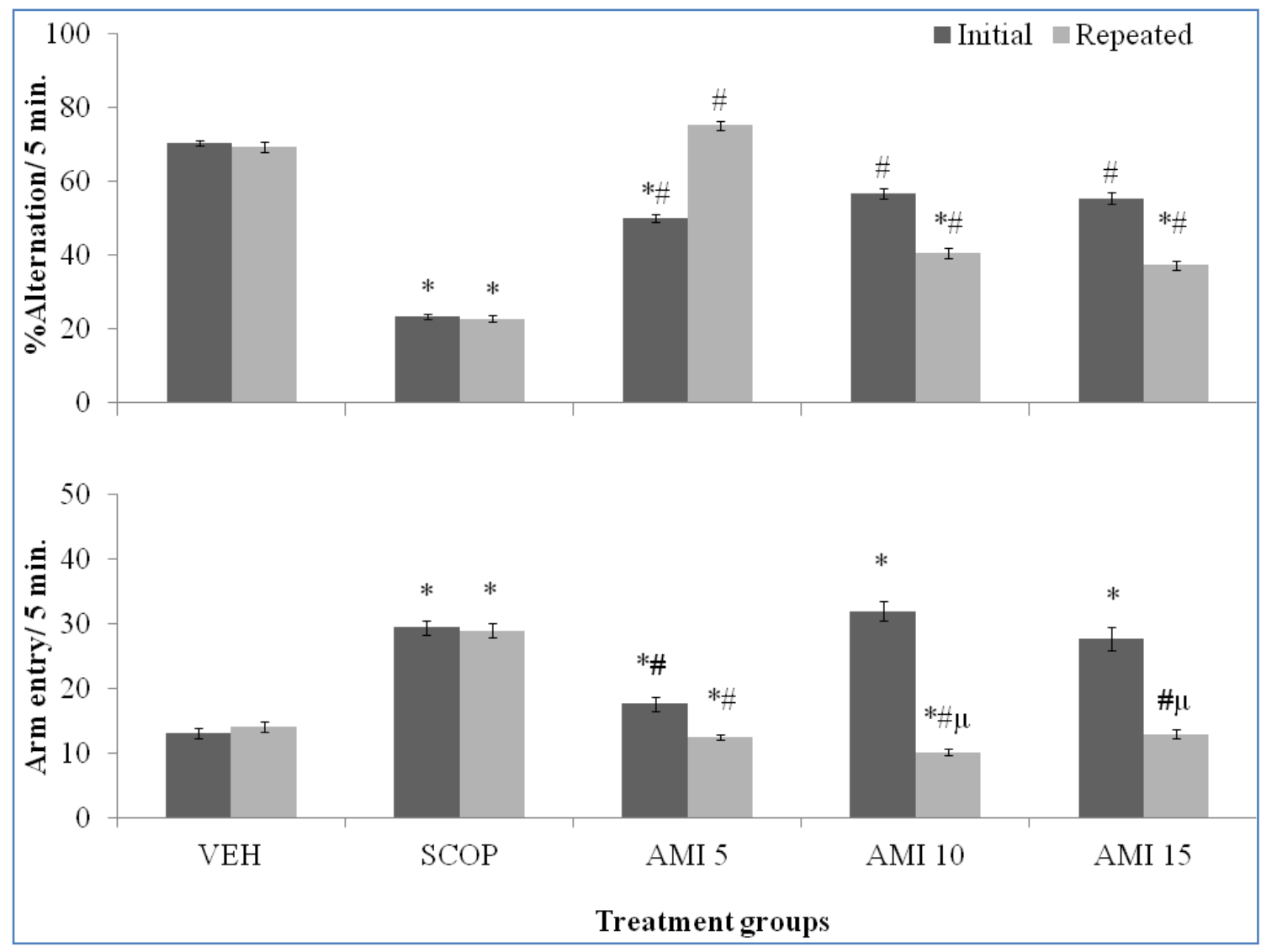

Figure 3. Effect of amitriptyline on spatial working memory (upper panel) and locomotor activity (lower panel) in the $\mathrm{Y}$-maze. Values are means \pm S.E.M. $\left({ }^{*} \mathrm{p}<0.05\right.$ significantly different from VEH, ${ }^{*} \mathrm{p}<0.05$ significantly different from SCOP, ${ }^{\mathrm{p}} \mathrm{p}<0.05$ repeated administration significantly different from initial administration). VEH: Vehicle, SCOP: Scopolamine, AMI: Amitriptyline, number of animals per group-10. 


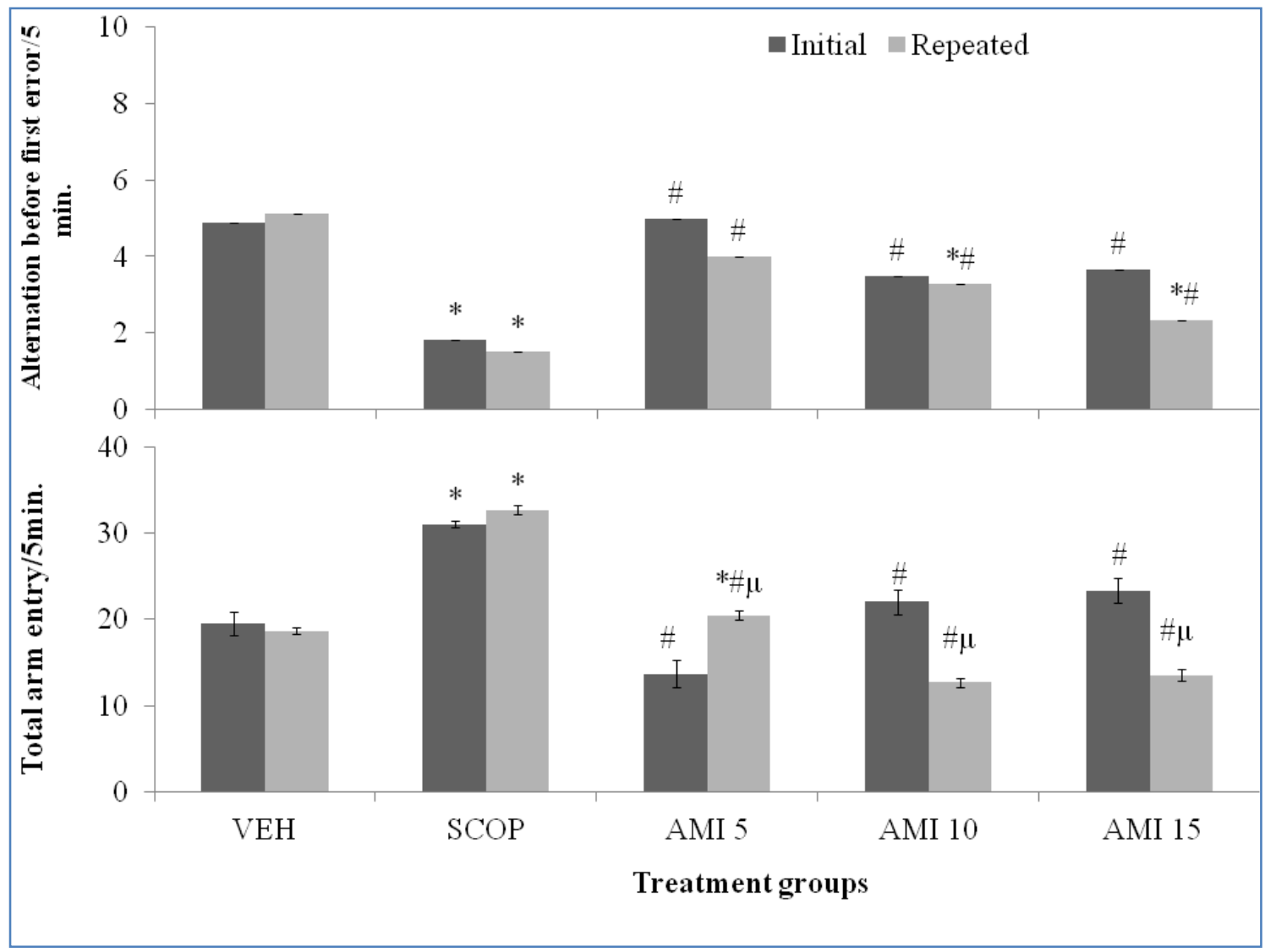

Figure 4. Effect of amitriptyline on spatial working memory (upper panel) and locomotor activity (lower panel) in the radial-arm maze. Values are means \pm S.E.M. ( ${ }^{*} \mathrm{p}<0.05$ significantly different from VEH, ${ }^{*} \mathrm{p}<0.05$ significantly different from $\mathrm{SCOP},{ }^{\mu} \mathrm{p}<0.05$ repeated administration significantly different from initial administration). VEH: Vehicle, SCOP: Scopolamine, AMI: Amitriptyline, number of animals per group-10.

\subsection{Effect of Amitriptyline on Radial Arm Maze Locomotor Activity}

Figure 4 (lower panel) shows the effect of vehicle, scopolamine and amitriptyline on locomotor activity in the radial-arm maze, measured as total arm entry within a 5 minute period. A two-factor ANOVA assessing the main effect of treatment and/or repeated administration, revealed a significant effect of treatment $\left(\mathrm{F}_{(4,50)}=6.68, \mathrm{p}<0.003\right)$ and repeated administration $\left(\mathrm{F}_{(1,50)}=14.00, \mathrm{p}<0.001\right)$, with no significant interactions between treatment $\mathrm{x}$ repeated administration $\left(\mathrm{F}_{(4,50)}=1.43, \mathrm{p}<0.001\right)$. Tukey HSD analysis revealed a significant increase in total arm entry with SCOP $(p<0.001)$ compared to vehicle, following initial administration; and a significant increase in arm entry with SCOP $(\mathrm{p}<0.001)$, and amitriptyline at $5 \mathrm{mg} / \mathrm{kg}(\mathrm{p}<0.001)$ with repeated administration. Compared to SCOP control, arm entry was significantly less with amitriptyline at 5 $(\mathrm{p}<0.010), 10(\mathrm{p}<0.011)$ and $15 \mathrm{mg} / \mathrm{kg}(\mathrm{p}<0.001)$ following initial and repeated administration. Pairwise comparisons of the effect of repeated administration revealed significantly higher arm entry with repeated administration of amitriptyline at $5 \mathrm{mg} / \mathrm{kg}(\mathrm{p}<0.001)$ and significantly less with amitriptyline at $10(\mathrm{p}<0.041)$ and $15 \mathrm{mg} / \mathrm{kg}(\mathrm{p}<0.010)$ compared to initial administration.

\section{Discussion}

Pharmacological agents such as amitriptyline are widely prescribed for depression, anxiety and several other disorders [26]. Drugs in this class are known to have various neuropharmacological effects; however, the presence of effects without desired clinical benefits may constitute impediments to therapy. This study set out to assess the effects of amitriptyline on open-field behaviours and working-memory in mice. From the present study, we deduced that repeated administration of amitriptyline causes: (1) a reduction in horizontal locomotion and rearing behaviours, in comparison to vehicle (2) a dose-related reduction in grooming frequency compared to scopolamine (3) and a dose-related deterioration in working-memory compared to vehicle.

The results of initial administration of amitriptyline showed an inverted-U response with lesser increases in horizontal locomotor and rearing activities at the extremes (5 and $15 \mathrm{mg} / \mathrm{kg}$ ), and a greater increase at the median dose compared to vehicle; however, with repeated dosing there is a blunting of this response. A fairly-similar response is observed when horizontal locomotor activity is compared to scopolamine control. A previous study had shown that in the elevated plus-maze, acute amitriptyline administration 
caused a significant dose-dependent reduction in entries into closed arms; which is considered a reliable measure of general activity [15]. The locomotor response observed with amitriptyline exceeded that of scopolamine at the median dose, after initial administration. Scopolamine had been reported to induce locomotor hyperactivity via effects on nigrostriatal dopaminergic neurons [27]. The higher locomotor activity associated with amitriptyline at $10 \mathrm{mg} / \mathrm{kg}$ would suggest the possibility of an influence on the dopaminergic system. Amitriptyline is known to inhibit the re-uptake of serotonin and noradrenalin, and it also increases the regional turnover of dopamine in parts of the brain that are crucial for locomotion [28]. Also, studies have shown that amitriptyline potentiates the effects of $\mathrm{D}_{3}$ dopamine receptors in the nucleus accumbens [8]. Dopamine pathways $\left(\mathrm{D}_{1}\right.$-like $\left(\mathrm{D}_{1}\right.$ and $\left.\mathrm{D}_{5}\right)$ and $\mathrm{D}_{2}$-like $\left(\mathrm{D}_{2}, \mathrm{D}_{3}\right.$, and $\left.\mathrm{D}_{4}\right)$ [29] play a role in mediating motor behaviours including locomotion and stereotyped behaviours. Numerous studies have shown that stimulation of the $\mathrm{D}_{3}$ receptors are inhibitory to both spontaneous and psychostimulant-induced locomotion, as opposed to concurrent $\mathrm{D}_{1}$ and $\mathrm{D}_{2}$ receptor-mediated effects [30-33]. The differences in response observed after initial and repeated administration of amitriptyline could be the result of drug exposure-dependent alteration in $\mathrm{D}_{3}$ receptor stimulation; with lesser modulation after initial administration and increased modulation with repeated administration. It is however worthy of note that some studies came to a different conclusion $[8,34]$ Therefore, the behavioural response of $\mathrm{D}_{3}$ receptor stimulation has been conflicting; with studies reporting an increase in spontaneous locomotor activity in $\mathrm{D}_{3}$ receptor mutant mice [35-37], but not in others $[38,39]$. The overall effect seen with repeated administration of amitriptyline could be attributed to a time-dependent down-regulation by $\mathrm{D}_{3}$ receptors of the transmission at postsynaptic $\mathrm{D}_{1}$ and $\mathrm{D}_{2}$ class receptors, which jointly control motor behaviours [35].

Grooming is a complex and centrally-controlled component of rodent behavioural repertoire which is known to serve several functions; and is regulated by multiple areas in the brain with influences from several neuromediators, neurotransmitters [40] and hormones [41]. In this study, amitriptyline was associated with an increase in novelty-induced grooming behaviours at all doses after initial administration, and an increase at the lowest dose with repeated administration. Increased grooming is an expected behavioural change after introduction of rodents to novel environments [42]; it is attributed to a stress response. Studies have reported a differential role of dopamine in the regulation of grooming behaviour; the activation of $D_{1}$ receptors induces intense grooming [43], which is inhibited by $\mathrm{D}_{2}$ receptors [44]. The GABA system also plays a role in the expression of novelty-induced grooming via $\mathrm{GABA}_{-\mathrm{A}}$ and $\mathrm{GABA}_{-\mathrm{B}}$ receptors [45]. $\mathrm{GABA}_{-\mathrm{A}}$ [46] and $\mathrm{GABA}_{-\mathrm{B}}$ [47] receptor agonists have been reported to cause a decrease in grooming. Recent studies have also reported that repeated but not initial administration of amitriptyline stimulates
$\mathrm{GABA}_{\mathrm{B}}$ receptors in mice [48]; this could be responsible for the significant reduction in grooming observed after repeated administration of amitriptyline. Serotonin is another neurotransmitter that modulates grooming activity. Amitriptyline's inhibition of serotonin reuptake results in an increase in serotonin concentration in the brain [11]. Stimulation of GABA release is mediated by $5-\mathrm{HT}_{2}$ [49] and $5-\mathrm{HT}_{3}[50]$ receptors; this in itself may also be responsible for the effects of amitriptyline on grooming.

Effects of antidepressants on memory have been linked to their neuropharmacological properties via interactions with cholinergic, histaminergic, serotonergic and noradrenergic neurotransmitter systems, which have strong links in modulation of learning and memory. In this study, scopolamine had an amnesic effect in the Y- maze and radial-arm maze, which is consistent with previously reported effects of scopolamine administration in mice. Amitriptyline (compared to vehicle) showed a dose-related spatial working-memory effects which ranged from no significant difference with vehicle, to a significant decrease in working-memory, irrespective of the memory paradigm used. Compared to scopolamine however, we saw better memory scores with amitriptyline at all doses studied in either the Y-maze, or radial-arm maze. The spatial working-memory task is a function of ambulatory activity. In this study, locomotor activity in the $\mathrm{Y}$ and radial arm maze decreased compared to either scopolamine or vehicle at certain doses, it did not (in our own view) impact on the results of the spatial memory tasks, because enough spontaneous alternations were made by each animal to make a statistically significant inference.

Effects of amitriptyline (like many other antidepressants) on memory have been considered as mere side-effects of its use [51]; therefore, there is a dearth of information on the effect of amitriptyline on memory. In this study, the result of amitriptyline's effects on spatial memory corroborates that of a number of studies that have reported impairment of memory following amitriptyline administration in rodents [52-54]. Even though this study differs from previous ones in the memory model employed (radial-arm maze and Y-maze versus the inhibitory avoidance paradigm $[15,55,56]$, the results were however comparable. A number of other studies have however reported that administration of amitriptyline was associated with memory improvements, usually in aged mice $[55,57,58]$. The age-related memory response has been attributed to a reduction in stress-related hormone levels and anxiety [55]. There are suggestions that amitriptyline's effects on memory are linked to both its anticholinergic and antihistaminergic effects [13]. Amitriptyline-induced memory-impairment is consistent with reports that drugs with anticholinergic effects cause memory-impairment [59]; however, the modulatory role of histamine (which could either cause an improvement or a deterioration of memory) is both task and brain-region specific [60]. Studies have reported task-associated memory deficits with amitriptyline [13]. The differences in memory 
response observed after initial and repeated administration of amitriptyline could be the result of drug exposure-dependent alteration of synaptic plasticity via modulation of long-term potentiation (LTP) or long-term depression (LTD). A few studies have observed memory-impairing effect of repeated amitriptyline use which was absent with single-dose administration, suggesting the influence of duration of administration on memory response [61]. There are suggestions that amitriptyline's ability to disrupt long-term potentiation (LTP) in the hippocampus [54] is a major mechanism for its long-term effect on memory. Alterations in synaptic plasticity have also been associated with deterioration in memory [62]. In this study, mice explored the radial-arm after they had explored the Y-maze; and we observed that amitriptyline administration resulted in dose-related spatial-memory deficit, consistently in both models (Y-maze and radial-arm maze). The radial-arm maze involves a recognition-memory element [63], which would mean that prior exposure to a similar maze (Y-maze) should cause a significant improvement in memory response in the radial-arm maze. However, the observation of deterioration in memory with amitriptyline could also imply a failure of recognition memory and not only spatial working-memory. Compared to scopolamine, memory test performance that were observed in both mazes after amitriptyline administration was an improvement; this suggests that at the doses tested, amitriptyline might not have caused a complete muscarinic receptor blockade, or the influence of other neurotransmitters/neuromodulators may be limiting the memory deterioration [13].

\section{Conclusions}

Oral administration of amitriptyline causes significant dose-related alterations in behaviours (open-field and spatial working-memory) in healthy mice. Considering its ever-increasing potential clinical applications, this study therefore provides an insight into the degree of cognitive and locomotor disability that may be associated with long-term amitriptyline therapy.

\section{Conflict of Interest}

All authors of this paper declare that there is no conflict of interest related to the content of this manuscript.

\section{REFERENCES}

[1] C. Leucht, M. Huhn, S. Leucht. Amitriptyline versus placebo for major depressive disorder. The Cochrane Database of Systematic Reviews. 12: 2012 CD009138. doi: 10.1002/14651858.
[2] I.K Grundt, H. Nyland. Activation of cultured glial cells by amitriptyline and platelet activating factor. Toxicology In Vitro 8: 1015-20, 1994.

[3] E. Obuchowicz, J. Kowalski, K. Labuzek, R. Krysiak, J. Pendzich, ZS Herman. Amitriptyline and nortriptyline inhibit interleukin-1 release by rat mixed glial and microglial cell cultures. International Journal of Neuropsychopharmacology. 9:27-35, 2006.

[4] M.F Flament, H. Bissada,W. Spettigue. "Evidence-based pharmacotherapy of eating disorders". International Journal of Neuropsychopharmacology 15: 189-207, 2012.

[5] Y.J. Sim, J.M Kim, S. Kwon B.H. Choe. Clinical experience with amitriptyline for management of children with cyclic vomiting syndrome. Korean Journal of Pediatrics. 52: 538-43, 2009. doi:10.3345/kjp.2009.52.5.538

[6] R.G. Boles, M.R Lovett-Barr, A. Preston, B.U. Li, K. Adams. Treatment of cyclic vomiting syndrome with co-enzyme Q10 and amitriptyline, a retrospective study". BMC Neurology 10: 10, 2010. doi:10.1186/1471-2377-10-10.

[7] Z.G. Mamedov. Change in the activity of cortical neurons under the influence of biogenic amines. Neurosci. Behavioural Physiology, 17:160-167 1987.

[8] J. Maj, M. Dziedzicka-Wasylewska, R. Rogoż, Z. Rogóż. Effect of antidepressant drugs administered repeatedly on the dopamine $\mathrm{D}_{3}$ receptors in the rat brain. European Journal of Pharmacology 351: 31-37, 1998.

[9] P.S. D'Aquila, M. Collu, G.L. Gessa, G. Serra. The role of dopamine in the mechanism of action of antidepressant drugs European Journal of Pharmacology 405: 365-373, 2000.

[10] I. Hindmarch, U. Rigney, N. Stanley, M. Briley. Pharmacodynamics of milnacipran in young and elderly volunteers. British Journal of Clinical Pharmacology 49: 118125, 2000. doi: 10.1046/j.1365-2125.2000.00124.x

[11] J. Hyttel, A.V. Christensen, B. Fjalland. Neuropharmacological properties of amitriptyline, nortriptyline and their metabolites. Acta Pharmacology Toxicology (Copenhagen) 47: 53-7, 1980.

[12] O.J Onaolapo, A.Y Onaolapo, M.A Akanmu, G Olayiwola (2016) Changes in Spontaneous Working-memory, Memory-recall and Approach-avoidance following "Low Dose" Monosodium Glutamate in Mice. AIMS Neuroscience, 3 (3): 317-337 DOI: 10.3934.

[13] A. Parra, E. Everss, M.C. Arenas, C. Vinader-Caerols, S. Monleón. Amitriptyline administered after consolidation of inhibitory avoidance does not affect memory retrieval Psicothema 18: 514-518, 2006.

[14] A. Parra, A. Ferrer-Añó, C.Fuentes, S. Monleón, C. Vinader-Caerols Effects of co-administration of amitriptyline and fluoxetine on inhibitory avoidance in mice. Behavioural Brain Research. 214: 343-8, 2010. doi: 10.1016/j.bbr.2010.06.002.

[15] A. Parra, E. Everss, S. Monleon, C. Vinader-Caerols, M.C. Arenas. Effects of acute amitriptyline administration on memory, anxiety and activity in male and female mice. Neuroscience Research Communications. 31: 135-144, 2002.

[16] I. Klinkenberg, A. Blokland. The validity of scopolamine as a pharmacological model for cognitive impairment: A review of 
animal behavioral studies. Neuroscience and Biobehavioural Reviews 34: 1307-1350, 2010.

[17] E. von Linstow Roloff, D. Harbaran, J. Micheau, B. Platt, G. Riedel. Dissociation of cholinergic function in spatial and procedural learning in rats. Neuroscience. 146: 875-889, 2007.

[18] K. Toide Effects of scopolamine on extracellular acetylcholine and choline levels and on spontaneous motor activity in freely moving rats measured by brain dialysis. Pharmacology Biochemostry and Behaviour 33:109-13, 1989.

[19] H.E. Shannon, S.C. Peters. A comparison of the effects of cholinergic and dopaminergic agents on scopolamine-induced hyperactivity in mice. Journal of Pharmacology and Experimental Therapeutics 255: 549-53, 1990.

[20] G. Poorheidari, A.J. Pratt, N. Dehghani. Effects of low-dose scopolamine on locomotor activity: No dissociation between cognitive and non-effects. Neuroscience Research Communication 31: 165-174, 2002.

[21] E.J. Kim, D.U. Jeong. Transdermal scopolamine alters phasic REM activity in normal young adults. Sleep. 22:515-520, 1999.

[22] O.J Onaolapo, A.Y. Onaolapo, M.A. Akanmu, G. Olayiwola. Foraging enrichment modulates open field response to monosodium glutamate in mice. Annals of Neuroscience 22: 162-170, 2014.

[23] A.Y. Onaolapo, O.J Onaolapo, P.U Nwoha. Alterations in behaviour, cerebral cortical morphology and cerebral oxidative stress markers following aspartame ingestion. Journal of chemical Neuroanatomy 78: 42-56, 2016.

[24] O.J. Onaolapo, A.Y. Onaolapo, E.O. Awe, N. Jibunor, B. Oyeleke. Oral artesunate-amodiaquine combination causes anxiolysis and impaired cognition in healthy Swiss mice. IOSR Journal of Pharmacy and Biological Sciences 7: 97-102, 2013. http://dx.doi.org/10.9790/3008-07297102.

[25] O.J. Onaolapo, A.Y. Onaolapo, O.R Akinola, T.O. Anisulowo. Dexamethasone regimens alter spatial memory and anxiety levels in mice. Journal of Behavioural and Brain Science 4: 159-167, 2014.

[26] R.J. Baldessarini. Drugs and the treatment of psychiatric disorders: depression and anxiety disorders. In: Hardman JG, Limbird LE, Gilman AG, editors. Goodman \& Gilman's; The pharmacological basis of therapeutics, 10th edition. New York: McGraw-Hil1 pg 447-483, 2001.

[27] G. Di Giovanni, W-x. Shi. Effects of scopolamine on dopamine neurons in the substantia nigra: role of the pedunculopontine tegmental nucleus. Synapse 63: 673-680, 2009.

[28] F.S. Messiha. Effects of a secondary and a tertiary amine tricyclic antidepressant on cerebral biogenic amines as a function of mouse strain: a comparative neurotoxicological evaluation. Toxicologic Letters58: 77-84, 1991.

[29] C. Missale, S.R. Nas, S.W. Robinson, M. Jaber, M.G. Caron. Dopamine receptors: From structure to function. Physiological Reviews. 78: 189-225, 1998.

[30] AM. Ouagazzal, I. Creese. Intra-accumbens infusion of D (3) receptor agonists reduces spontaneous and dopamine-induced locomotion. Pharmacology Biochemistry and Behaviour. 67: $637-645,2000$.
[31] K. D Carr, N. Yamamoto, M. Omura, S. Cabeza de Vaca, L. Krahne. Effects of the D (3) dopamine receptor antagonist, U99194A, on brain stimulation and d-amphetamine reward, motor activity, and c-fos expression in ad libitum fed and food-restricted rats. Psychopharmacology (Berlin) 163: 76-84, 2002.

[32] L.M Pritchard, A.D Logue, S. Hayes, J.A Welge, M. Xu, J. Zhang, S.P Berger et al. 7-OH-DPAT and PD 128907 selectively activate the D3 dopamine receptor in a novel environment. Neuropsychopharmacology 28: 100-107, 2003.

[33] L. Zhang, D. Lou, H. Jiao, D. Zhang, X. Wang, Y. Xia, J. Zhang, et al. Cocaine-induced intracellular signalling and gene expression are oppositely regulated by the dopamine D1 and D3 receptors. Journal of Neuroscience 24: 3344-3354, 2004.

[34] C.H Lammers, J. Diaz, J.C Schwartz, P. Sokoloff. Selective increase of dopamine D3 receptor gene expression as a common effect of chronic antidepressant treatments Molecular Psychiatry 5: 378-388, 2000.

[35] M. Xu, T.E Koeltzow, G.T Santiago, R. Moratalla, D.C Cooper, $\mathrm{X}-\mathrm{u} \mathrm{Hu}$, et al. Dopamine D3 receptor mutant mice exhibit increased behavioral sensitivity to concurrent stimulation of D1 and D2 receptors. Neuron 19: 837-848, 1987.

[36] D. Accili, C.S Fishburn, J. Drago, H. Steiner, J.E Lachowicz, B.H Park et al. A targeted mutation of the D3 dopamine receptor gene is associated with hyperactivity in mice. Proceedings of the National Academy of Science USA. 93: 1945-1499, 1996.

[37] D. Vallone, M. Pignatelli, G. Grammatikopoulos, L. Ruocco, Y. Bozzi, H. Westphal et al. Activity, non-selective attention and emotionality in dopamine D2/D3 receptor knock-out mice. Behavioural Brain Research 130: 141-148, 2002.

[38] J.D Joseph, Y.M Wang, P.R. Miles, E.A Budygin, R. Picetti, R.R Gainetdinov et al. Dopamine autoreceptor regulation of release and uptake in mouse brain slices in the absence of D (3) receptors. Neurosci 112:39-49, 2002.

[39] F.N McNamara, J.J Clifford, O. Tighe, A. Kinsella, J. Drago, S. Fuchs et al. Phenotypic, ethologically based resolution of spontaneous and $\mathrm{D}(2)$-like vs $\mathrm{D}(1)$-like agonist-induced behavioural topography in mice with congenic $\mathrm{D}(3)$ dopamine receptor "knockout" Synapse 46: 19-31, 2002.

[40] A.P Serafim, L.F Felicio. Dopaminergic modulation of grooming behavior in virgin and pregnant rats. Brazillian Journal of Medicine and Biological Research. 31: 1465-1470, 2004.

[41] A.J Dunn, C.W Berridge, Y.I Lai, T.L Yachabach. CRF-induced excessive grooming behaviour in rats and mice. Peptides 8: 841-4, 1987.

[42] A.J Stoessl. Dopamine D1 receptor agonist induced grooming is blocked by the opiod receptor antagonist maloxone. European Journal Pharmacology 259: 301-303, 1996.

[43] J. Komorowska, S.M Pellis. Regulatory mechanisms underlying novelty-induced grooming in the laboratory rat, Behav. Processes, 67:287-293, 2004.

[44] B.S Starr, M.S Starr. Differential effects of dopamine D1 and D2 agonists and antagonists on velocity of movement, rearing and grooming in the mouse. Implications for the roles of D1 and D2 receptors. Neuropharmacology 25: 455-463, 1986. 
[45] H.M Barros, S.L Tannhauser, M.A Tannhauser, M. Tannhauser. The Effects of GABAergic drugs on grooming behaviour in the open field. Pharmacology and Toxicology 74: 339-344, 1994.

http://dx.doi.org/10.1111/j.1600-0773.1994.tb01370.x

[46] M.S Nin, N.S Couto-Pereira, M.F Souza, L.A Azeredo, M.K Ferri, W. L Dalprá, et al. Anxiolytic effect of clonazepam in female rats: Grooming microstructure and elevated plus maze tests. European Journal of Pharmacology 684: 95-101, 2012.

[47] J.L Silverman, M.C Pride, J.E Hayes, K.R Puhger, H.M Butler-Struben, S. Baker et al. $\mathrm{GABA}_{\mathrm{B}}$ receptor agonist r-baclofen reverses social deficits and reduces repetitive behaviour in two mouse models of autism.

Neuropsychopharmacology 40: 2228-2239, 2015.

[48] J.A Gray, A.R Green. Increased GABA-в receptor function in mouse frontal cortex after repeated administration of antidepressant drugs or electroconvulsive shocks. British Journal of Pharmacology 92: 357-362, 1987.

[49] G.K Aghajanian, G.J Marek. Serotonin induces excitatory postsynaptic potentials in apical dendrites of neocortical pyramidal cells. Neuropharmacology 36:589-99, 1997.

[50] S. Katsurabayashi, H. Kubota, N. Tokutomi, N. Akaike. A distinct distribution of functional presynaptic 5-HT receptor subtypes on GABAergic nerve terminals projecting to single hippocampal CA1 pyramidal neurons. Neuropharmacol. 44: 1022-30, 2003.

[51] H. González-Pardo, N.M Conejo, J.L Arias, S. Monleón, C. Vinader-Caerols, A. Parra. Changes in brain oxidative metabolism induced by inhibitory avoidance learning and acute administration of amitriptyline. Pharmacology Biochemistry Behaviour 89: 456-62, 2002. doi: 10.1016/j.pbb.2008.01.022.

[52] F. Pavone, M. Battaglia,M. Sansone. Prevention of amitriptyline-induced avoidance impairment by tacrine in mice. Behavioural Brain Research 89: 229-36, 1997.

[53] E. Everss, M.C Arenas, C. Vinader-Caerol, S. Monleón, A. Parra. Piracetam counteracts the effects of amitriptyline on inhibitory avoidance in CD1 mice. Behavioural Brain Research 159: 235-42, 2005.
[54] G. Zarei, P. Reisi, H. Alaei, S.H Javanmard. Effects of amitriptyline and fluoxetine on synaptic plasticity in the dentate gyrus of hippocampal formation in rats. Advances in Biomedical Research. 3: 199, 2014. doi: $10.4103 / 2277-9175.142044$

[55] Yau JL, Olsson T, Morris RG, Meaney MJ, Seckl JR (2002) Glucocorticoids, hippocampal corticosteroid receptor gene expression and antidepressant treatment: relationship with spatial learning in young and aged rats. Neurosc. 66: 571-581.

[56] A. Parra, C. Vinader-Caerols, A. Ferrer-Añó, A. Urquiza, S. Monleón. The effect of amitriptyline on inhibitory avoidance in mice is dose-dependent. Psicothema 21: 528-30, 2009.

[57] W. Chadwick, N. Mitchell, J. Caroll, Y. Zhou, S-s Park, L. Wang, K.G Becker et al. Amitriptyline-mediated cognitive enhancement in aged $3 \times \operatorname{tg}$ alzheimer's disease mice is associated with neurogenesis and neurotrophic activity. PLoS ONE 6. e21660, 2001. doi:10.1371/journal.pone.0021660

[58] R.J Branconnier, D.R DeVitt, J.O Cole, K.F Spera. Amitriptyline selectively disrupts verbal recall from secondary memory of the normal aged. Neurobiology of Aging. 3: 55-9, 1982.

[59] P.E Gold. Acetylcholine modulation of neural systems involved in learning and memory. Neurobiolology of Learning and Memory. 80: 194-210, 2003.

[60] P. Blandina, M. Efoudebe, G. Cenni, P. Mannaioni, M.B Passani. Acetylcholine, histamine and cognition: two sides of the same coin. Learning and Memory. 11:1-8,2004

[61] R.A Stein, T. Strickland. A review of the neuropsychological effects of commonly used prescription medications. Arch.ives of Clinical Neuropsychology. 13: 259-284, 1998.

[62] T. Takeuchi, A.J Duszkiewicz, R.G.M Morris. The synaptic plasticity and memory hypothesis: encoding, storage and persistence. Philos Trans R Soc Lond B Biological Science 369,2014

[63] AM Stranahan. Similarities and differences in spatial learning and object recognition between young male $\mathrm{C} 57 \mathrm{Bl} / 6 \mathrm{~J}$ mice and Sprague-Dawleyrats. Behavioural Neuroscience 125: 791-795, 2011. doi: 10.1037/a0025133. 